\title{
Implementasi Sistem Pendukung Keputusan Dengan Metode SAW Dalam Pemilihan Guru Terbaik
}

\author{
Implementation Of A Decision Support System With SAW Method In Selecting The Best \\ Teacher
}

\author{
Nadia Dwi Apriani*1, Novita Krisnawati ${ }^{2}$, Yola Fitrisari ${ }^{3}$ \\ 1,2,3 Program Studi Teknik Informatika, STIKOM Poltek Cirebon \\ e-mail:*1nadiadwiapriani9@gmail.com, ${ }^{2}$ novitakrisnawati4@gmail.com, ${ }^{3}$ yolafitrisari2@gmail.com
}

\begin{abstract}
Abstrak
Memiliki guru yang profesional merupakan suatu keharusan bagi sekolah dalam melaksanakan proses belajar mengajar yang bermutu, demikian pula dengan SMKN 1 Kadipaten. Oleh sebab itu, sekolah selalu mendorong peningkatan kualitas guru dengan cara memantau kerja guru dalam menerapkan tugasnya sehingga dapat mencapai standar kompetensi yang telah ditentukan. Sistem pendukung keputusan secara umum didefenisikan sebagai sebuah sistem yang mampu menghasilkan pemecahan maupun penanganan masalah. Sistem pendukung keputusan tidak dimaksudkan untuk menggantikan peran pengambil keputusan, tapi untuk membantu dan mendukung pengambil keputusan. Salah satu metode yang sering digunakan dalam sistem pendukung keputusan adalah metode Simple Additive Weighting (SAW). Metode Simple Additive Weighting (SAW) ini dipilih karena dapat menentukan nilai bobot untuk setiap atribut, kemudian dilanjutkan dengan proses perankingan yang akan menyeleksi alternatif terbaik dari sejumlah alternatif yang ada. Dalam hal ini alternatif yang dimaksud adalah penentuan guru terbaik pada SMKN 1 Kadipaten menggunakan metode SAW (simple additive weighting). Dengan metode perangkingan tersebut diharapkan penilaian akan lebih tepat karena didasarkan pada nilai kriteria dan bobot yang sudah ditentukan sehingga akan mendapatkan hasil yang lebih maksimal.
\end{abstract}

Katakunci: SPK, SAW, guru berprestasi

\begin{abstract}
Abstrack
Having a professional teacher is a must for schools in conducting quality teaching and learning process, as well as SMKN 1 Kadipaten. Therefore, schools always encourage quality improvement of teachers by monitoring the work of teachers in implementing their duties so as to achieve a predetermined standard of competence. Decision support systems are generally defined as a system capable of producing solutions and problem solving. Decision support systems are not intended to replace decision-making roles, but to assist and support decision makers. One of the most commonly used methods in decision support systems is the Simple Additive Weighting (SAW) method. Simple Additive Weighting (SAW) method is chosen because it can determine the weight value for each attribute, then proceed with a ranking process that will select the best alternative from a number of alternatives. In this case the alternative is the determination of the best teacher in SMKN 1 Kadipaten using SAW method (simple additive weighting). With the ranking method is expected to be more appropriate assessment because it is based on the criteria and weight of the predetermined so that will get maximum results.
\end{abstract}

Keyword: DSS, SAW, teacher achievement

\section{PENDAHULUAN}

Selama ini cara yang digunakan untuk penentuan guru berprestasi di SMKN 1 Kadipaten yaitu menggunakan penentuan Indeks Penilaian Guru dan dilakukan secara manual. Bagi guru yang memiliki jumlah nilai terbesar, maka guru tersebut berhak menjadi guru berprestasi dan akan mendapatkan penghargaan dari Lembaga Sekolah. Proses pemilihan guru berprestasi saat ini masih dipengaruhi oleh unsur subjektifitas dari panitia yang memilih, 
sehingga dirasakan kurang mendukung proses tersebut. Apabila terjadi ketidaktepatan tim penilai dan murid dalam memberikan penilaian kepada setiap guru karena adanya beberapa kriteria yang bersifat subjektif, maka penilaian diberikan masih bersifat tidak pasti dan tidak jelas karena dimungkinkan muncul ketidaktepatan dalam memberikan nilai kepada guru yang akan berdampak pada hasil pemilihan terhadap guru diberikan menjdi kurang akurat dan tepat. Untuk mengatasi permasalahan tersebut, maka penulis mecoba untuk membuat suatu sistem pendukung keputusan dengan menggunakan metode simple additive weighting (SAW) untuk membantu proses pemilihan guru berprestasi di SMKN 1 Kadipaten. Pembuatan SPK ini diharapkan akan menyelesaikan permasalahan yang dihadapi, dan menghasilkan rekomendasi keputusan yang bisa membantu Tim Penilai untuk menentukan siapa yang benar-benar layak mendapat predikat guru berprestasi. Umumnya variable yang dapat digunakan untuk menentukan guru berprestasi diantaranya kedisiplinan, absensi, kemampuan mengajar, prakarsa, prestasi, tanggungjawab, serta dapat menjaga nama baik[1][2], selain itu untuk pemilihan guru terbaik dibidang komputer diantaranya memiliki pendidikan terakhir S1, memiliki pengalaman mengajar, menguasi bidang komputer, dan nilai IPK minimal 3.0 [3].

Penelitian akan menggunakan SAW karena pada perhitungannya memungkinkan terjadinya kesamaan nilai vector untuk alternatif dengan nilai kriteria yang berbeda, selain itu hasil rangking pada SAW akan menjadi lebih karena memperhitungkan juga penentuan preferensi alternatif berdasarkan solusi ideal positif dan solusi ideal negatif[4]. Untuk uji validasi secara fungsional metode SAW memiliki kesesuaian 92\% dari 50 data yang diujikan[5].

\section{METODE PENELITIAN}

Metode penelitian yang penulis gunakan adalah mix method dengan model sequential explanatory. Model kombinasi ini digunakan secara berurutan, dimana urutan pertamanya yaitu menggunakan metode kuantitatif dan urutan kedua menggunakan metode kualitatif. Penelitian kuantitatif dengan teknik pengumpulan data yang utama adalah kuesioner. Selanjutnya untuk mengecek dan memperbaiki kebenaran data dari kuesioner tersebut maka dilakukan pengumpulan data dengan dengan metode kualitatif yaitu dengan teknik observasi dan wawancara[6].

Metode SAW sering juga dikenal istilah metode penjumlahan terbobot[7]. Konsep dasar metode SAW adalah mencari penjumlah terbobot dari rating kinerja pada setiap alternatif dari semua kriteria[8]s. Metode ini memerlukan langkah perhitungan normalisasi matriks keputusan (X) ke suatu skala yang dapat dibandingkan dengan semua rating alternatif yang ada. Metode SAW mengenal dua jenis kriteria, yaitu cost dan benefit. Cost merupakan jenis kriteria yang mengutamakan nilai terendah, sedangkan benefit merupakan jenis kriteria yang mengutamakan nilai tertinggi sebagai acuan pemilihan[9]. Prosedur atau langkah-langkah untuk menerapkan metode SAW meliputi[10]:

a. Menentukan kriteria (C) yang akan dijadikan acuan dalam pengambilan keputusan.

b. Memberikan nilai bobot (W) dari masing-masing kriteria yang telah ditentukan.

c. Memberikan nilai rating kecocokan pada masing-masing alternatif dari semua kriteria.

$$
\mathrm{X}=\left[\begin{array}{ccc}
x 11 & \cdots & x i j \\
\vdots & \cdots & \vdots \\
x 21 & \cdots & x i j
\end{array}\right]
$$

persamaan (1)

d. Menghitung matriks keputusan berdasarkan kriteria (C), selanjutnya dilakukan perhitungan normalisasi matriks berdasarkan persamaan yang disesuaikan dengan jenis atribut (cost atau benefit), sehingga didapatkan hasil nilai kinerja ternormalisasi matriks (rij). 


$$
\begin{aligned}
& R i j=\frac{X i j}{M a x X i j} \text { Jika j adalah atribut keuntungan (benefit) persamaan (2) } \\
& R i j=\frac{M i n R i j}{R i j} \mathrm{Jika} \mathrm{j} \text { adalah atribut biaya (cost) persamaan (3) }
\end{aligned}
$$

Hasil dari nilai kinerja ternormalisasi (rij) membentuk matriks ternormalisasi (R).

$$
R=\left[\begin{array}{ccc}
r 11 & \cdots & r i j \\
\vdots & \cdots & \vdots \\
r 21 & \cdots & r i j j
\end{array}\right]
$$

persamaan (4)

e. Hasil akhir didapatkan dari proses penjumlahan dari perkalian matriks ternormalisasi (R) dengan vektor bobot yang kemudian dilakukan perangkingan, sehingga didapatkan nilai alternatif tertinggi sebagai solusi terbaik.

$$
V_{i}=\sum_{j=1}^{n} W_{j} r_{i j}
$$

Keterangan:

persamaan (5)

$\mathrm{V}_{\mathrm{i}}$ : rangking untuk setiap alternatif

$\mathrm{W}_{\mathrm{j}}$ : nilai bobot dari setiap kriteria

$\mathrm{r}_{\mathrm{ij}} \quad$ : nilai rating kinerja ternormalisasi

\section{HASIL DAN PEMBAHASAN}

\section{Menentukan Kriteria(C)}

Menentukan kriteria yang akan dijadikan sebagai acuan untuk pemilihan guru terbaik. Adapun kriteria tersebut terdapat pada Tabel 1.

Tabel 1. Tabel kriteria

\begin{tabular}{cc}
\hline Kode & Kriteria \\
\hline C1 & Ijazah \\
\hline C2 & Sertifikasi \\
\hline C3 & Absen \\
\hline C4 & Kedisiplinan \\
\hline C5 & Tanggung jawab \\
\hline
\end{tabular}

\section{Menentukan Bobot Masing-masing (W)}

Penentuan bobot masing-masing kriteria menggunakan persen. Kriteria yang dianggap prioritas utama diberi bobot lebih tinggi dibanding kriteria yang dianggap prioritas rendah. Tabel 2 adalah tabel nilai bobot masing-masing kriteria

Tabel 2. Tabel nilai bobot

\begin{tabular}{ccc}
\hline Kriteria (C) & Keterangan & Bobot \\
\hline C1 & Ijazah & $30 \%$ \\
\hline C2 & Sertifikasi & $20 \%$ \\
\hline
\end{tabular}




\begin{tabular}{ccc}
\hline C3 & Absen & $20 \%$ \\
\hline C4 & Kedisiplinan & $15 \%$ \\
\hline C5 & Tanggung jawab & $15 \%$ \\
\hline Total bobot & & $100 \%$
\end{tabular}

Memberikan nilai rating kecocokan pada masing-masing alternatif dari semua kriteria

Pada tahap ini dilakukan pengumpulan data guru sesuai dengan kriteria yang telah ditentukan. Table 3 adalah nilai rating kecocokan pada masing-masing alternatif

Tabel 3. Data guru

\begin{tabular}{cccccc}
\multirow{2}{*}{ Alternatif } & \multicolumn{5}{c}{ Kriteria } \\
\cline { 2 - 6 } & C1 & C2 & C3 & C4 & C5 \\
\hline A1 & 70 & 60 & 80 & 50 & 70 \\
\hline A2 & 80 & 70 & 70 & 80 & 50 \\
\hline A3 & 60 & 50 & 80 & 80 & 70 \\
\hline
\end{tabular}

\section{Menormalisasi Matrik (R)}

Sebelum melakukan proses normalisasi matriks, terlebih dahulu menentukan jenis kriteria cost atau benefit. Dalam kasus ini semua kriteria yang ada adalah kriteria benefit atau keuntungan.

Kriteria ijazah (C1) - benefit

Nilai $\operatorname{Max} \mathrm{X}_{\mathrm{ij}}=\{70 ; 80 ; 60\}=80$

$\mathrm{r}_{11}=\frac{70}{80}=0,875$

$r_{21}=\frac{80}{80}=1$

$r_{31}=\frac{60}{80}=0,75$

Kriteria sertifikasi (C2) - benefit

Nilai Max $\mathrm{X}_{\mathrm{ij}}=\{60 ; 70 ; 50\}=70$

$\mathrm{r}_{12}=\frac{60}{70}=0,857$

$\mathrm{r}_{22}=\frac{70}{70}=1$

$r_{32}=\frac{50}{70}=0,71$

Kriteria absen (C3) - benefit

Nilai Max $\mathrm{X}_{\mathrm{ij}}=\{80 ; 70 ; 80\}=80$

$r_{13}=\frac{80}{80}=1$ 


$$
\begin{aligned}
& r_{23}=\frac{70}{80}=0,875 \\
& r_{33}=\frac{80}{80}=1
\end{aligned}
$$

Kriteria kedisiplinan (C4) - benefit

Nilai $\operatorname{Max} \mathrm{X}_{\mathrm{ij}}=\{50 ; 80 ; 80\}=80$

$$
\begin{aligned}
& r_{14}=\frac{50}{80}=0,625 \\
& r_{24}=\frac{80}{80}=1 \\
& r_{34}=\frac{80}{80}=1
\end{aligned}
$$

Kriteria tanggung jawab (C5) - benefit

Nilai $\operatorname{Max} \mathrm{X}_{\mathrm{ij}}=\{70 ; 50 ; 70\}=70$

\begin{tabular}{|c|c|c|c|c|c|}
\hline \multirow{4}{*}{$\mathrm{R}$} & $\mathrm{C} 1$ & $\mathrm{C} 2$ & C3 & $\mathrm{C} 4$ & C5 \\
\hline & 0,875 & 0,857 & 1 & 0,625 & 1 \\
\hline & 1 & 1 & 0,875 & 1 & 0,714 \\
\hline & 0,75 & $\overline{0,714}$ & 1 & 1 & 1 \\
\hline
\end{tabular}

$$
\begin{aligned}
& r_{15}=\frac{70}{70}=1 \\
& r_{25}=\frac{50}{70}=0,714 \\
& r_{35}=\frac{70}{70}=1
\end{aligned}
$$

Setelah melakukan proses normalisasi nilai dari masing-masing alternatif pada setiap kriteria, maka didapat matrik normalisasi seperti table 4.

Tabel 4. Tabel matrik normalisasi

\section{Perangkingan}

Pada tahap perangkingan terdapat proses penjumlahan dari hasil perkalian matriks ternormalisasi dengan nilai bobot. Hasil perhitungan tersebut kemudian dilakukan perangkingan. Alternatif yang memiliki nilai tertinggi menjadi rekomendasi terbaik dalam menentukan keputusan. Berikut merupakan contoh perhitungan proses perangkingan:

$$
\begin{aligned}
& \mathbf{V}_{\mathbf{1}}=(0,3)(0,875)+(0,2)(0,857)+(0,2)(1)+(0,15)(0,625)+(0,15)(1)=0,877 \\
& \mathbf{V}_{\mathbf{2}}=(0,3)(1)+(0,2)(1)+(0,2)(0,875)+(0,15)(1)+(0,15)(0,714)=0,932 \\
& \mathbf{V}_{\mathbf{3}}=(0,3)(0,75)+(0,2)(0,714)+(0,2)(1)+(0,15)(1)+(0,15)(1)=0,867
\end{aligned}
$$


Hasil dari perhitungan nilai perankingan di atas dapat dilihat pada tabel 5.

Tabel 5. Tabel Hasil Perangkingan

\begin{tabular}{ccc}
\hline Ranking & Alternatif & Nilai \\
\hline 1 & A2 & 0,932 \\
\hline 2 & A1 & 0,877 \\
\hline 3 & A3 & 0,867 \\
\hline
\end{tabular}

Dari tabel 5 telah didapatkan bahwa A2 memiliki nilai tertinggi di antara dua alternatif lainnya. Sehingga dari contoh kasus di atas dapat disimpulkan bahwa metode SAW telah memberikan rekomendasi terbaik pada A2. Setelah melakukan perhitungan manual tersebut, penulis akan mencoba menerapkannya ke dalam suatu perancangan yang menggunakan pendekatan object orinted melalui use case diagram dan activity diagram.

Berikut use case diagram:

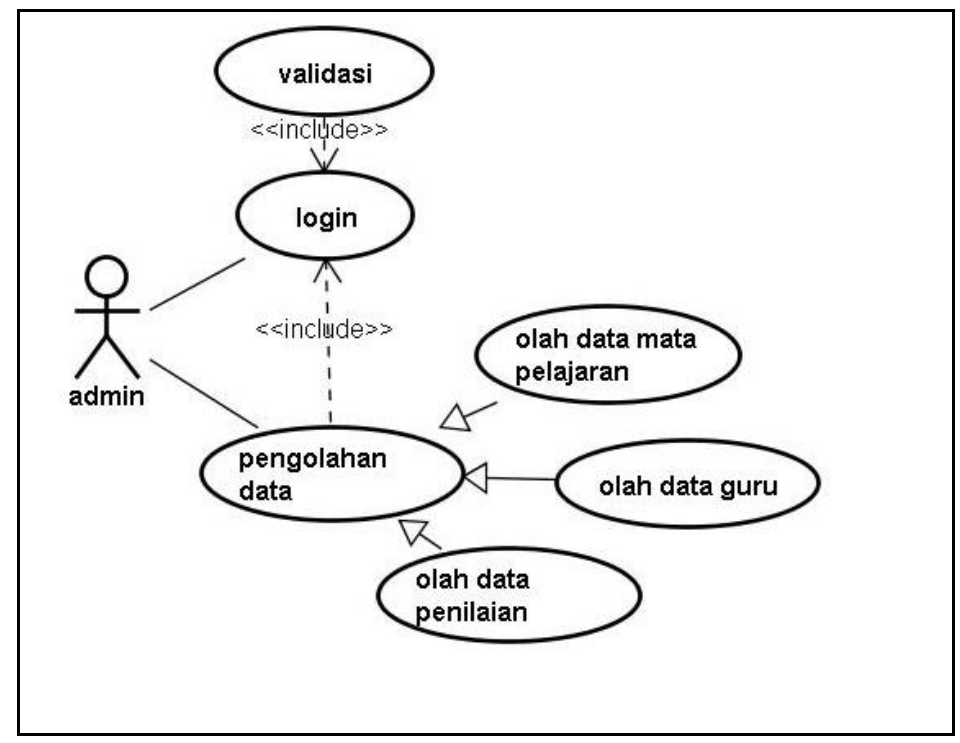

Gambar 1. Use case diagram

Berdasarkan gambar use case tersebut dapat dilihat bahwa user yang terlibat dengan sistem yaitu admin. Admin dapat melakukan pengolahan data yang meliputi olah data pelajaran, olah data guru dan olah data penilaian. Admin juga dapat melakukan input, edit dan hapus data. Sebelum masuk ke dalam sistem, admin terlebih dahulu melakukan proses login yang akan di validasi oleh sistem.

Sedangkan dari gambar 2, maka proses input data guru dapat dijelaskan bahwa proses dimulai dari admin melakukan penginputan biodata guru, lalu sistem menerima inputan yang kemudian sistem melakukan validasi data. Jika data yang di inputkan tidak lengkap atau salah maka proses akan kembali ke admin dimana admin harus melengkapi kembali data tersebut. Sementara apabila data yang diinputkan benar dan sudah lengkap maka proses akan berlanjut pada penyimpanan data tersebut ke dalam tabel data guru di database. Pada gambar 3 menjelaskan mengenai alur input data nilai. Proses dimulai dari admin yaitu memilih data guru yang akan di seleksi. Selanjutnya admin mengiputkan nilai pada kriteria yang kemudian akan di validasi oleh sistem. Apabila data sudah lengkap dan benar maka sistem akan menyimpan nilai kriteria pada tabel penilaian. Sementara apabila data tidak lengkap maka proses akan kembali ke tahap penginputkan nilai pada kriteria yang dilakukan admin. 


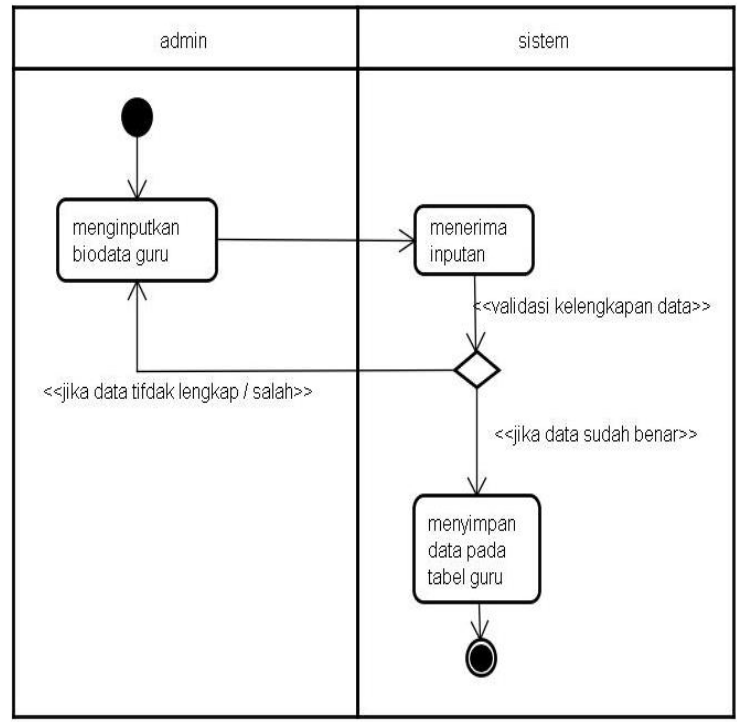

Gambar 2. Activity diagram input data guru

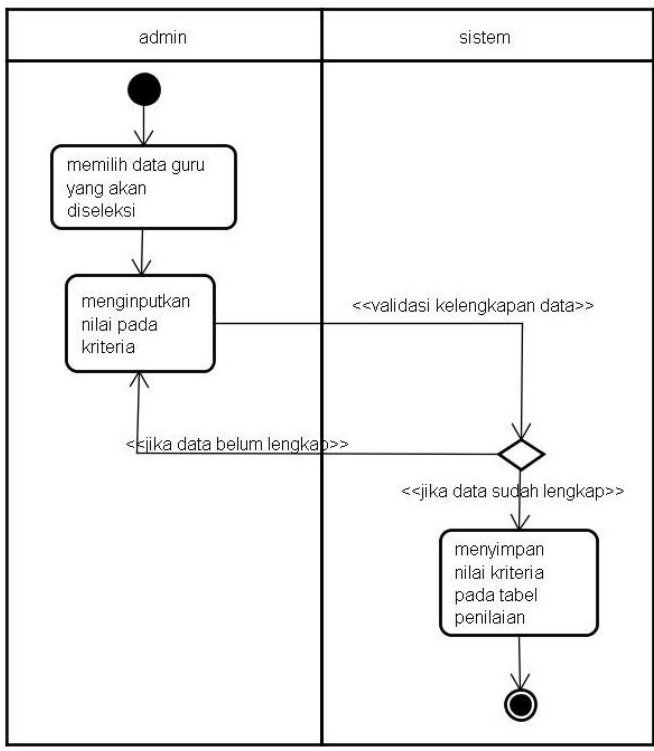

Gambar 3. Activity diagram input data nilai

Berdasarkan gambar 4, admin akan melakukan analisis SAW dengan cara menekan tombol analisis SAW. Setelah itu sistem akan melakukan analisis SAW dimana terlebih dahulu sistem melakukan pengecekan banyaknya kriteria dan banyaknya alternatif. Selanjutnya sistem akan melakukan perhitungan SAW berdasarkan nilai pada alternatif dan bobot kriteria. Lalu sistem menampilkan hasil alternatif terbaik. 


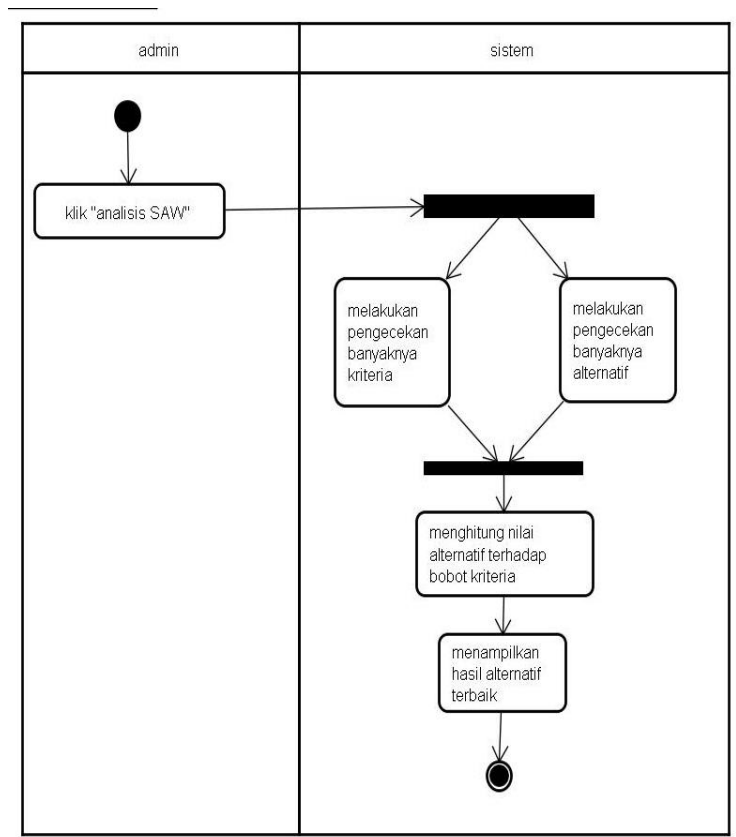

Gambar 4. Activity diagram analisis SAW

\section{KESIMPULAN}

Berdasarkan hasil pembahasan di atas, maka dapat disimpulkan bahwa metode SAW mampu menangani masalah pengambilan keputusan pemilihan guru terbaik. Proses penentuan nilai bobot merupakan tahapan di luar metode SAW, namun nantinya akan dipergunakan dalam proses perhitungan. Nilai bobot yang dihasilkan berdasarkan masukan pengguna, sehingga setiap pengguna memiliki nilai prioritas yang berbeda-beda. Dengan dibangunnya SPK ini dapat mempermudah pihak sekolah dalam memilih guru terbaik. Pada tahap selanjutnya semoga perancangan ini dapat dibuat secara lebih detail dan dapat diimplementasikan ke dalam pengembangan sistem.

\section{DAFTAR PUSTAKA}

[1] R. S. Hutasoit, A. P. Windarto, D. Hartama, and S. Solikhun, "Sistem Pendukung Keputusan Pemilihan Guru Terbaik Pada SMK Maria Goretti Pematangsiantar Menggunakan Metode Simple Additive Weighting (SAW)," JURASIK (Jurnal Ris. Sist. Inf. Tek. Inform., vol. 1, no. 1, 2016.

[2] F. Duwiyanti and M. Ardhiansyah, "Sistem Pendukung Keputusan Pemilihan Guru Terbaik di SMK Pustek Serpong Dengan Menggunakan Metode TOPSIS," Int. J. Educ. Sci. Technol. Eng., vol. 2, no. 1, pp. 45-67, 2019, doi: 10.36079/lamintang.ijeste0201.18.

[3] J. Simarmata, T. Limbong, M. Aritonang, and S. Sriadhi, "Sistem Pendukung Keputusan Pemilihan Guru Bidang Studi Komputer Menggunakan Metode Simple Additive Weighting (Saw)," Comput. Eng. Sci. Syst. J., vol. 3, no. 2, p. 186, 2018, doi: 10.24114/cess.v3i2.10400.

[4] R. A. Sugianto, R. Roslina, and Z. Situmorang, "Kombinasi Metode Simple Additive Weigthing dan Weigthed Product Untuk Seleksi Proposal Program Kreatifitas 
Mahasiswa," J. Media Inform. Budidarma, vol. 5, no. April, pp. 564-572, 2021, doi: 10.30865/mib.v5i2.2929.

[5] A. W. Setiyono and A. S. Purnomo, "Lead Management System Sales Dengan Simple Additive Weighting ( SAW )," KONSTELASI Konvergensi Teknol. dan Sist. Inf., vol. 1, no. 2, 2021.

[6] M. Santi and A. Prajana, "Analisis Implementasi Ujian Nasional Berbasis Komputer Dengan Ujian Berbasis Kertas Di Smpn 3 Ingin Jaya Kabupaten Aceh Besar," Cybersp. J. Pendidik. Teknol. Inf., vol. 2, no. 2, p. 84, 2019, doi: 10.22373/cj.v2i2.3997.

[7] F. A. Sianturi and M. Sitorus, "KOMBINASI METODE SIMPLE ADDITIVE WEIGHTING (SAW) DENGAN ALGORITMA NEAREST NEIGHBOR UNTUK REKRUITMEN KARYAWAN,” J. Mantik Penusa, vol. 3, no. 2, pp. 38-45, 2019.

[8] T. Hidayat, F. Widiyanto, and Y. K. Hasim, "Rancang Bangun Decision Support System Pemilihan Guru Terbaik Menggunakan Metode Simple Additive Weighting ( Saw ) ( Studi Kasus : Sma Bhakti Pertiwi Kota Tangerang )," JUTIS J. Informatics Eng., vol. 5, no. 1, pp. 52-56, 2017.

[9] A. Sayoko, I. Widihastuti, and A. Riansyah, "Implementasi Metode Simple Additive Weighting (Saw) Untuk Menentukan Penerima Penghargaan Adiwiyata Pada Sekolahan Kabupaten Semarang," Pros. Konf. Ilm. Mhs. UNISSULA 2, pp. 420-427, 2019, [Online]. Available: http://lppmunissula.com/jurnal.unissula.ac.id/index.php/kimueng/article/view/8611.

[10] I. Nur Okta and B. Satria, "Sistem Pendukung Keputusan Dalam Menentukan Perbaikan Jalan Rusak Dengan Menggunakan Metode Simple Additive Weighting (SAW) (Studi Kasus : Kabupaten Kuantan Singingi)," Jar. Sist. Inf. Robot., vol. 3, no. 1, pp. 194-202, 2019. 